\title{
Works analysis in training design
}

How ergonomics helps to orientate upstream design of virtual training environments

L'analyse des travails pour la conception en formation. Contribution de l'ergonomie à l'orientation de la conception amont d'un environnement virtuel pour la formation

\section{Vincent Boccara and Catherine Delgoulet}

\section{(2) OpenEdition}

\section{Journals}

\section{Electronic version}

URL: http://journals.openedition.org/activites/1109

DOI: 10.4000/activites.1109

ISSN: $1765-2723$

\section{Publisher}

ARPACT - Association Recherches et Pratiques sur les ACTivités

\section{Electronic reference}

Vincent Boccara and Catherine Delgoulet, «Works analysis in training design », Activités [Online] 12-2 | 2015, Online since 15 October 2015, connection on 02 May 2019. URL : http:// journals.openedition.org/activites/1109; DOI : 10.4000/activites.1109

\section{c) (7) $\Theta$}

Activités est mis à disposition selon les termes de la licence Creative Commons Attribution - Pas d'Utilisation Commerciale - Pas de Modification 4.0 International. 


\title{
Works analysis in training design. \\ How ergonomics helps to orientate upstream design of virtual training environments
}

\author{
Vincent Boccara \\ CNRS-LIMSI, Rue John Von Neumann, Bat. 508, F-91403 Orsay Cedex. Université Paris-Sud, Bat. 452, \\ F-91403 Orsay Cedex - boccara@limsi.fr \\ Catherine Delgoulet \\ Université Paris Descartes, Laboratoire Adaptations Travail-Individus (LATI), 76 avenue Édouard Vaillant, F-92550 \\ Boulogne-Billancourt - catherine.delgoulet@parisdescartes.fr
}

\begin{abstract}
S
A works analysis approach for designing professional training. The contribution of ergonomics in orienting the upstream design of a virtual reality environment. The aim of this article is to present and discuss a works analysis approach. This approach was developed within the context of a design project aiming to build a virtual environment for training (VET) workers involved in the assembly of aircraft parts. The frameworks of ergonomics and professional didactics served as a background for this study which took place in three stages: 1) an analysis of both demand and project, 2) work analysis (trainers, trainees and production unit workers, and 3) a coanalysis device to co-analyse work knowledge and its transmission by trainers. During the study, the focal point of work analysis, the people concerned and the results produced by ergonomists all evolved and became more complex. Using reflection on our own ergonomic practice, we discuss the benefits of works analysis as a means of identifying the wide range of training situations and of taking part in design projects.
\end{abstract}

\section{KEYWORDS}

conception, training, virtual environment, work analysis, aeronautics

This article reflects on an approach to works analysis with a view to taking part in the design of a training tool. More specifically, we will focus on how such an approach helps to orient design choices for a virtual training environment demonstrator. Its purpose is therefore to help produce models for ergonomist participation in design and, more particularly, in the field of professional training. It is rooted in a multidisciplinary design research project (bringing together a manufacturing company and one of its subsidiary sites, computer engineers, automation engineers, designers and ergonomists) upstream of a virtual training environment (VTE) for aeronautical assemblers 1. As ergonomists, our initial brief came in two parts: 1) to analyse existing professional situations in order to write learning situations into the VTE and 2) to assess the VTE's "internal and external relevance" (Delgoulet, 2001) when it comes to learning a given profession. We only discuss the first part here.

1 The "Natural Interactions, Knowledge, Immersive system for Training in Aeronautics" (NIKITA) research project, funded by the Agence National pour la Recherche (ANR) and coordinated by Domitile Lourdeaux from the Heudiasyc laboratory at the Université Technologique de Compiègne (http://www.emissive.fr/nikita/). 
This project thus relates to the initial phases of tool development, those of two versions of demonstrator design: in two dimensions using a "screen-keyboard" format, or in three dimensions using an "immersive" approach. The demonstrator is designed to integrate existing professional training devices, a tool a priori designed to become both a training instrument ${ }^{2}$ for trainers and a learning instrument for the future professionals being trained. From our standpoint, such a purpose requires implementation of work analysis in the sense of Daniellou (1996, p. 185), i.e. "the global approach, where the activity analysis is integrated into an analysis of the economic, technical and social factors with which the operator is faced, and an analysis of the effects of the company's operations on the population in question and of economic efficiency". We developed a "works analysis" approach to trainers, trainees and production operators at the crossroads of approaches defended in ergonomics and professional training (Boccara \& Delgoulet, 2013; Chatigny \& Vézina, 2008; Olry \& Vidal-Gomel, 2011; Ouellet, Vézina, \& Chatigny, 2013; Pastré, 2011).

Our approach therefore examines the place of works analysis, its scope and the actors involved, so that ergonomists can help to design a training tool (definition of objectives, training devices and situations, properties of the virtual environment and of the manipulated objects, tool functionalities, etc.). Without going into the details of all of the analyses performed, we discuss "works" analysis as a means of identifying the multiple horizons of the training situations to be defined: "training for what?", "training how?", “what device(s)?", "for what purposes?" (Olry \& Vidal-Gomel, 2011), considering working conditions for training to be learning conditions for trainees (Chatigny \& Vézina, 2008; Ouellet, Vézina, \& Chatigny, 2013). To conclude, we return to the potential contributions that this approach can make to ergonomic intervention in the field of training design.

\section{1.- The theoretical framework of the approach}

VTE design has been the subject of numerous works which tend to focus on support technologies (non-immersive and immersive Virtual Reality, or Augmented Reality), the information manipulated in or by these tools and how it is presented (e.g. Brough, Schwartz, Gupta, Anand, Kavetsky, \& Pettersen, 2007; Costello, 1997). More rarely, analyses focus on users (mainly on trainees) and their needs (Anastassova, Burkhardt, Mégard, \& Ehanno, 2007) and consider tasks as they are prescribed in work situations (e.g. Hu, Zhang, \& Salvendy, 2012). The activity and the conditions for its situational development are virtually ignored, which leads to an approach to learning based on presuppositions or prescriptions which do not allow one to consider the variability and diversity of real situations for the accomplishment of tasks and their transposition into learning situations.

In ergonomics of activity and professional learning, training course design traditionally uses real work situations as a reference (Haradji, Kostulski, Morais, \& Ughetto, 2014). However, when designing a new training tool, as is the case here, we make the hypothesis that these situations cannot be the sole point of reference if, prior to the design, we wish to take account of all actors and situations likely to be affected by the modified tool. It is therefore more a case of identifying baseline situations (Samurçay \& Rogalski, 1998) which are pertinent to probable future situations, so as to direct and act during the process of designing the new training tool (Daniellou, 2004). As the design concerns training, these baseline situations fall into two categories: 1) production work and 2) training work.

\section{1.- Analysing activity for training course design}

Since the first works on ergonomics of activity (Leplat, 1955; Montmollin de, 1974; Ombredane \& Faverge, 1955; Pacaud, 1975), researchers have helped inform the field of professional training (for a more comprehensive review, see: Teiger \& Lacomblez, 2013). Prudent and sporadic for some considerable time, the number of works began to increase in the early 1990s (Rabardel, Teiger,

2 In the sense of Rabardel (1995, p. 74), an instrument is "a mixed entity [...] a totality consisting of both an artefact (or a fraction of an artefact) and one or more schemes of use." 
Laville, Rey, \& Desnoyers, 1991; Teiger \& Montreuil, 1996). Their contributions to training design are now numerous and may be divided into four main categories:

1. Analysis of activity in work situations to identify training objectives and the critical skills which must be taught in order to equip workers (Berglund \& Karltun, 2012; Chatigny \& Vézina, 1995; Leppänen, 2001; Montmollin de, 1974; Ouellet \& Vézina, 2008), to design pedagogical tools to meet the needs of trainees and trainers (Anastassova, Burkhardt, Mégard, \& Ehanno, 2005; Aubert-Blanc, 2009; Boccara \& Delgoulet, 2013; Olry \& Vidal-Gomel, 2011), to identify the skills which are acquired and which may be transferred with a view to occupational retraining (Rabardel \& Six, 1995), to identify the difficulties in appropriating the knowledge and know-how seen during the training and to retrospectively evaluate the training courses (Delgoulet, 2001; Gaudart, 2000);

2. Analysis of the learning activity to identify what learners find easy or difficult when appropriating knowledge in work situations (Delgoulet \& Marquié, 2002; Santos \& Lacomblez, 2007; CauBareille, Gaudart, \& Delgoulet, 2012);

3. Analysis of the activity of transmission/sharing knowledge and know-how in work situations (tutorship, trade guilds, etc.; Cloutier, Fournier, Ledoux, Gagnon, Beauvais, \& Vincet-Genod, 2012; Delgoulet, Largier, \& Tirilly, 2013; Gaudart, Delgoulet, \& Chassaing, 2008; Thébault, Gaudart, Cloutier, \& Volkoff, 2012; Thébault, Delgoulet, Fournier, Gaudart, \& Jolivet, 2014) or during initial or further training (Anastassova \& Burkhardt, 2009; Messing, Escalona, \& Seifert, 1996; Rogalski, 2003; Veyrac \& Asloum, 2009; Viau-Guay, 2014; Vidal-Gomel, Boccara, Rogalski, \& Delhomme, 2012) in order to characterise interactions between trainers/teachers and trainees, to propose pedagogical tools which are relevant to situations and needs, or organisational arrangements which facilitate the joint activity of learning in work or training situations;

4. Training in and through the analysis of work done by actors in the fields of healthcare and occupational risk prevention or employee representation to transform their representations of the job and of the actions to engage in (Gaudart et al., 2012; Hubault, Noulin, Dupont, \& Mélier, 1994; Teiger \& Lacomblez, 2013; Teiger \& Laville, 1991; Wendelen, 1996); these works have also led to reflection on the evaluation of such programmes and their effects (Berthelette, 1995; Desnoyers, Berthelette, Gourde, \& Authier, 1997; Lang, 2013; Montreuil, Brisson, Arial, \& Trudel, 1997).

Our contribution stands at the meeting point of the first three themes and offers ergonomists an approach for works analysis and intervention analysis in the field of professional training design. The originality of our stance lies most particularly in the fact that the training situation is considered as a work situation. This assumption is based on three complementary arguments: 1) trainers are workers caught within socioeconomic issues of viability, of quality, of the performance levels of the training tools that they design, coordinate and/or facilitate; their activity is subject to constraints and must meet requirements just as much as that of production operators; 2) the trainees receiving professional training are employees of a company (a temporary employment agency or a company in the aeronautics sector); their work can therefore be taken to be "a work of learning" (Montmollin, 1980) which has to be linked to the context in which it takes place; 3 ) these training works (of both trainers and trainees) challenge and must orient the way the training is designed, in the same way as the more "obvious" work of production operators.

From our point of view, it is therefore a question of developing an approach to works analysis which allows us to take account of the baseline situations which are relevant to production and training, in order to design a new device or tool that might transform the conditions under which training is provided. The scope of ergonomic work analysis thus includes both the situations of production targeted at the end of training and the training situations themselves (Boccara \& Delgoulet, 2013; Beaujouan, Aubert, \& Coutarel, 2013).

\section{2.- Joint analysis of the work activity of trainers and trainees}

The work done by trainers was for a long time neglected by ergonomists and psycho-ergonomists; 
when they did look at transmission activities or activities to accompany employed or unemployed people in the construction of knowledge, they focused more on academic ergonomics from the learners' perspective. Their works examined school timetables (Delvolvé \& Davila, 1994), how children's work stations and tools were adapted or designed (Jacobs \& Backer, 2002), the activity of teachers in the classroom (Amigues, 2003; Faïta, 2003; Ria, Sève, Durand, \& Bertone, 2004; Rogalski, 2003, 2004), their working conditions (Jobert, 1987; 1993; 2000; Méhaut, 1995) and their impact on health (Cau-Bareille, 2011; Chatigny, Levesque, \& Riel, 2012; Delgoulet, 2012; Riel \& Messing, 2011; Santos \& Feirrera, 2012).

We base ourselves here on the model of teaching activity proposed by Rogalski (2003), in order to apprehend trainer work activity from a triple standpoint: professional, educational and in relation to the management of an open dynamic environment (Boccara, 2011; Vidal-Gomel et al., 2012). However, our approach aims to go beyond an analysis of trainer activity conducted independently of that of trainees or supplemented by an analysis of trainee activity. Our aim is to try to simultaneously understand the activity of both trainers and trainees using a dual approach (Rogalski, 2012) based on the model of dual regulation of work activity (Leplat \& Cuny, 1984). Schematically speaking, this proposition is an attempt to go beyond approaches which analyse training situations from the standpoint of the trainer/teacher and/or trainee either separately or from an interactionist viewpoint by putting oneself in the position of the activity deployed by the actors involved: trainer(s) and trainee(s).

This approach thus considers that the determinants of the situation are the determinants of the trainer's and trainees' activity, which echoes the propositions of the Quebec works which consider working conditions during training to be conditions of learning (Chatigny \& Vézina, 2008; Ouellet \& Vézina, 2008; 2009; Ouellet et al., 2003). Moreover, it also considers the activity of the trainee(s) to be a determinant of the activity of the trainer(s), and vice versa. The trainer-trainee activity can thus be considered to be a co-construction which is situated, dynamic, evolutive, multifaceted, multidimensional and multifunctional. It therefore has characteristics in common with (though not limited to) formative interactions which are constitutive elements of professional transmission ${ }^{3}$ as defined by Thébault (2013), i.e.: "interactions which attempt to have an effect on others, which are designed to teach, to contribute towards their development" (our translation, p. 115) in situations of production or service.

\section{3.- From situations of characteristic action to their didactic transposition}

In ergonomics and professional didactics, training course design is based on the identification and analysis of characteristic situations of action (Daniellou, 2004) in order to recommend training objectives (Olry \& Vidal-Gomel, 2011; Chatigny \& Vézina, 2008; Ouellet, Vézina \& Chatigny, 2013; Beaujouan, Aubert, \& Coutarel, 2013), by formalising baseline professional knowledge (Samurçay \& Rabardel, 2004) that is considered to be the content in which people need to be trained from a work standpoint. Some works have added to this approach by also analysing determinants of work situations upstream of training design, considering that improvements to trainers' working conditions will improve the learning conditions of trainees (Ouellet, Vézina \& Chatigny, 2013; Ouellet \& Vézina, 2008, 2009; Ouellet et al., 2003).

Far rarer however, is research on the educational transpositions (Olry \& Vidal-Gomel, 2011; Samurçay \& Rogalski, 1998) which are at work in existing training situations as opposed to "production" situations. Yet it would seem important to identify the differences and similarities between these two types of situation from the point of view of the activities deployed, those which cannot be deployed and those which it would be recommended to deploy in order to improve trainee learning and the development of their activity. The analysis of these differences might orient training

3 "A set of exchanges relating to professional practices, during the accomplishment of work, between individuals with different trajectories, experiences and levels of seniority, these exchanges being marked by the asymmetries that this diversity implies between said individuals." (our translation, p. 112) 
course design and, more specifically, the design of a new training tool, the introduction of which would be likely to modify the conditions under which trainer-trainee activity is conducted. So if we consider that this type of project relates to the design of a new artefact of instrumental vocation (Rabardel, 1995) for trainers and trainees, the analysis of these differences is one of the potential avenues that ergonomists might choose in order to examine what is desirable or possible during the design process (Daniellou, 2004). The project of a new artefact being a potential source for opening up the field of possibilities for trainer-trainee activity - as well as the constraints which might close it off or even prevent it (Clot, 2000) - ergonomists must be careful to encourage the former without fuelling the latter.

From this point of view, the aim of the works analysis approach is to produce a frame of reference for training situations (Mayen, Métral, \& Tourmen, 2010). This frame of reference would be an intermediate object within the design project (Jeantet, 1998; Vinck, 2009), the development of which could be pursued through its use by trainers after the design phase. The idea here is that this frame of reference might one day become one of the instruments used by trainers to construct potential development situations for trainees. In this sense the proposed approach aims to support the development of the actors to whom it relates.

\section{2.- Investigation approach and methodology}

\section{1.- Works analysis approach}

Our approach consisted of three phases: building the project, defining the objectives of the research in partnership with all of the actors involved and considering the specificities of the three baseline situations already generically identified. These three phases involved (cf. Figure 1):

- an analysis and reformulation of the demand: classic in ergonomics but far less so in this type of project, it allowed us to involve the strategic actors at our partner's site (in production, prevention, training or in relation to the site's CHSCT $^{4}$ ); to discuss the benefits, conditions and possibilities of having access to real production and training situations; in this specific case this included an analysis of the project, its history, its structures and its management;

- analyses of the work done by trainers, trainees and production operators, conducted at both organisational and situational levels; this involved working on issues of the transposition between production work and training work on the one hand, and, on the other, to study the sensitive period of taking up duties in the production workshop - the period between training work and production work;

- a joint analysis of professional know-how and its transmission ${ }^{5}$ within the framework of a methodological device involving trainers. This third phase is part of the more general work analysis and focuses on an aspect that is central to the design of a VTE - that of the skills used and developed in a profession. Two objectives orient this phase: a) to gain a better understanding of the critical skills which underpin the activity of assemblers; b) to give trainers an opportunity to develop their own activity as trainers by encouraging reflexive activities in relation to these critical skills and to their development during training (Weill-Fassina \& Pastré, 2004).

Taken together, these phases make it possible to build and gradually enrich the design clues on which ergonomists can communicate and base themselves throughout the lifetime of the project, in order to interact with the actors in charge of actual implementation of the scenarii, the properties of the manipulated elements within the virtual environment and related physical phenomena. In this case the

4 Comité Hygiène Sécurité et Conditions de Travail (hygiene, safety and working conditions committee)

5 The term "transmission" here refers to the joint activity of trainers and trainees in situ, oriented by the development of the trainee's skills. 
design clues came in the shape of a frame of reference for training situations within and with the VTE.

Works analysis is used on the one hand as a means to understand the activity of the different actors and identify professional know-how, and on the other hand as a resource to intervene both in situations of professional training as it currently exists, and during the design of a new training tool - in this case a VTE.

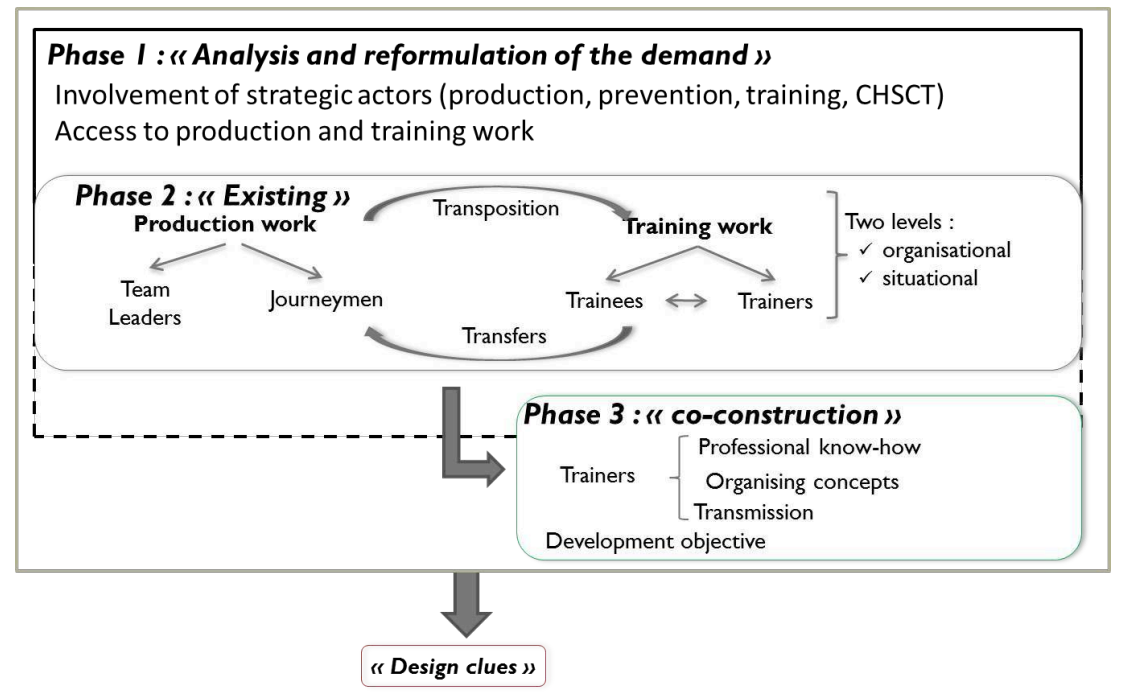

Figure 1: Schematization of the three phases of the works analysis approach

\section{2.- The baseline situation}

A production and training (both initial and professional site belonging to a subsidiary of our industrial partner was chosen as the project's baseline site. It specialises in the assembly of the front sections of aircraft (forward fuselages and cockpits). Approximately 1500 employees work at the production site every day. The "journeyman" population (the assemblers), mostly male, is made up of two relatively distinct age groups which form a bimodal demographic profile (the under-30s and the over-45s). The seniority of the journeymen is broadly age-related and evolves in parallel. For the most part, entry into the profession occurs at the start of one's working life, as a full-time company employee after a period of initial training (at professional Baccalauréat ${ }^{6}$ level) at the on-site training centre. It can also take the form of a temporary contract which includes a ten-week professional training course, eight weeks of which take place at the training centre, with a further two weeks of tutorship at a production station. After their training has been validated by obtaining the Certificat de Qualification Professionnelle de la Métallurgie (CQPM - certificate of professional qualification in metallurgy) and after one or more periods of temporary work, these workers can become full-time employees.

$96 \%$ of the trainees ${ }^{7}$ who follow the professional training course are men; they form a population which is heterogeneous in terms of age, professional experience, initial training and level of qualifications. Two thirds are under 25 years old and $19 \%$ are over $30.15 \%$ have a technical qualification (two-year post-high-school diploma), 47\% have a high-school diploma (professional or technical) and 33\% have either a professional aptitude certificate (CAP) or a professional studies diploma (BEP), in some cases both. The trainees have generally had some initial training (essentially mechanical) outside the aeronautics sector.

In this company "trainer" is not a structured profession in itself; it is a position which is held on a parttime or full-time basis. Nor is this role formally integrated into the career paths of the journeymen at the production site - unlike what happens in other companies (a means of occupational rehabilitation

\footnotetext{
${ }^{6}$ Approximate equivalent of US high-school diploma (HSD).

${ }^{7}$ This analysis was performed on a population of 163 trainees who had received training between 2010-2012.
} 
and/or evolution at end-of-career; a means of starting a career). On the contrary, the training entity even has problems "extracting" journeymen from production situations so that they can become intermittent or full-time trainers. More specifically, training is coordinated and run by two trainers over the age of fifty who are nearing retirement. They both have over 30 years' experience in production (as journeymen on production lines or as technical managers). One of them has been a trainer for two years, the other for one. They have received no training for this; they learned "on the job", from previous trainers.

In order to meet increasing needs for manpower, the production site makes huge demands of the training centre's two training branches (initial and professional).

\section{3.- Gathering data}

Because the project was based on an essentially qualitative approach, using empirical data from real work or training situations, we chose to triangulate the methods used (Guilbert \& Lancry, 2007; Jick, 1979; Leplat, 2002). This triangulation consisted in combining several different methods of data collection, in order to: 1) reduce the biases inherent to each method and thus increase the reliability and validity of the empirical data gathered; 2) to provide a qualitative richness and a better understanding of the phenomenon studied; 3 ) to facilitate understanding of processes which cannot be directly observed, such as conceptualisation in action (Pastré, 1999). This approach thus combines various classic ergonomic methods: field observations (Guérin, Laville, Daniellou, Duraffourg, \& Kerguelen, 1991; Rabardel, Carlin, Chesnais, Lang, \& Pascal, 1998), exploratory interviews (Blanchet \& Gotman, 1992) or self-confrontation interviews (Clot, Faïta, Fernandez, \& Scheller, 2000; Falzon \& Mollo, 2004), and a documentary collection (Guérin, et al., 1991). Our work analysis was thus based on fourteen days of field work (eight on training and six on production), on twenty semi-structured interviews and on two 4-hour self-confrontation sessions with each trainer. The empirical corpus thus created came from various sources. For this reason, a fieldwork diary (Arborio \& Fournier, 1999) was kept throughout the project in order to maintain the coherency of the overall objective of work analysis in terms of project orientation, and of the upstream design of a VTE. This journal allowed us to recreate the chronology of the events which constituted the design project (Boccara \& Delgoulet, 2013), and to ensure the temporal intersection of the data collected and the content produced.

During the training, observation days were organised in such a way as to gain an overview of how temporary workers were trained during their time on the workshop line. We conducted exploratory interviews with the two resident trainers, in order to delimit and understand their work. Other interviews were also conducted with 20 trainees from three distinct groups, at a specific moment in their learning trajectory on the workshop line: on group at the start, one in the middle and one at the end of the training. The objectives of these interviews were to trace their professional pathways and to identify both their evolution during training and what they found to be difficult or easy during the learning process. We also collected and analysed a certain number of documents: the training programme, lecture material and technical sheets containing exercises on the workshop line.

At the production site, two work stations were selected after discussions between the training centre managers, the site ergonomist and the production manager: the cockpit of one type of aircraft, designated by the term "forward point", and the forward fuselage of another type of aircraft, referred to as the "hull". These actors felt that these two stations were satisfactory examples of the main assembly tasks that journeymen have to perform. They allowed us to understand the wide variety of situations (operations, fittings, parts, types of aircraft) and production rhythms (depending on the type of plane being assembled), the existence of unforeseen events (supply, employees per station, cluttered work spaces, accessibility of the items to be assembled, etc.) and the collective aspect of the work (sharing work spaces and tools, performing tasks in teams of two). They also met the company's

\footnotetext{
${ }^{8}$ Due to a temporary absence of production at the "forward point" station during the period of our empirical data collection,
} most of our observations were made at the second station. 
requirements and expectations in terms of protecting industrial secrets, production continuity ${ }^{9}$, perennial operations within the provisional production schedules (no sub-contracting planned for the future) and professional constraints - in particular the physical constraints inherent to the profession. We also gathered a set of data relating to the population and work accidents, produced or collected by the human resources and occupational risk prevention departments. For reasons of industrial secrecy, we were only allowed to consult documents concerning work orders and the traceability of work done by the journeymen: station documents, production schedule, technical specifications and assembly monitoring sheets.

The co-construction device deployed during phase 3 involved only the trainers. It consisted in: 1) selecting an existing task that the trainers would perform; 2) filming the trainers while they performed the task; 3) conducting a self-confrontation interview with each trainer.

The task chosen (exercise 1), with agreement from the two trainers, presented the advantage of including a wide range of sub-tasks, processes and tools of the profession; it could be carried out in one day without interfering with the arrival of a group of trainees on the workshop line. Two cameras were used to film each trainer throughout the day (a total of 16 hours of video): the subjective camera allowed us to see the trainer's field of vision while the task was being performed and to get as close as possible to the visual acuity that the profession demands; the external camera filmed the same trainer and his working environment. Parallel editing of the two recordings gave us an overview of the scene as it unfolded and facilitated later discussions during the self-confrontation interviews (cf. Figure 2). During the interviews, we asked the trainers to watch the video sequence (with the possibility of using slow motion, fast-forwarding, or pausing) and to comment on the phases they felt to be important. Pauses were an opportunity to ask them about the objectives of transmitting knowledge to trainees and about the practical modalities. These self-confrontation interviews were filmed and transcribed. Their specific aim was to understand the conceptual aspect of the work carried out by the assemblers (Pastré, $1999,2005,2011)$ as they performed four elementary tasks required in the assembly profession (drilling, counter-boring, reaming and riveting), central to training.

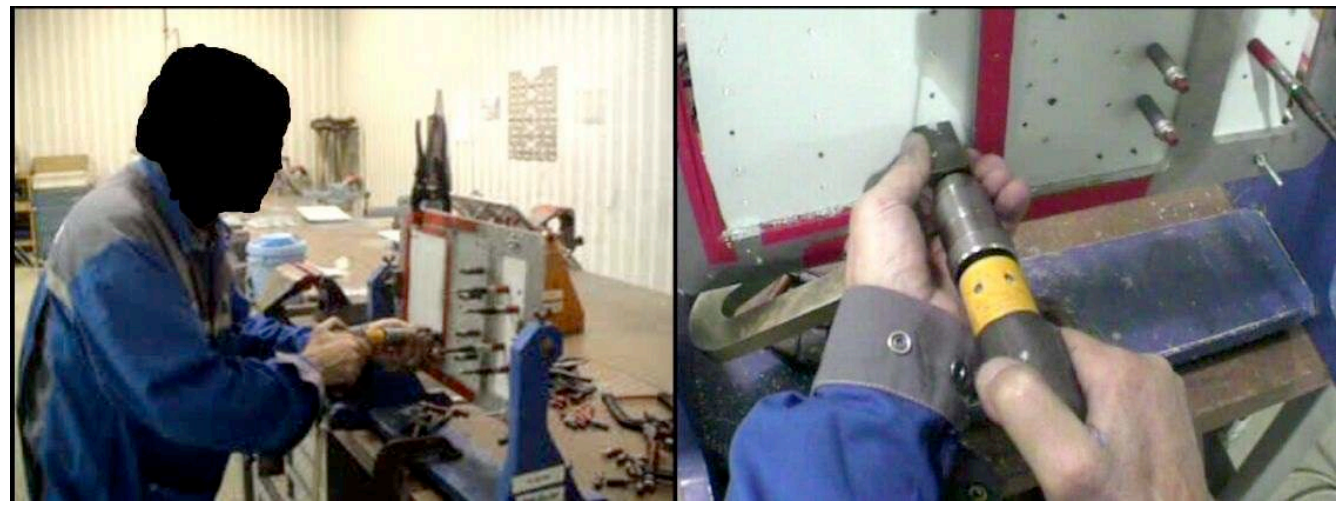

Figure 2: An example of video playback after editing film from the two cameras (external on the left and subjective on the right)

\section{3.- Above and beyond the analysis of what already exists in production}

\section{1.- Analysis and reformulation of the initial demand: towards a more global and shared approach}

The aim of the project was to propose a virtual environment which offered a balance between three

\footnotetext{
${ }^{9}$ The presence of one or two researchers at the station was not allowed to disrupt the journeymen's work. Because space was sometimes restricted at certain work stations, it was not always possible for observers to be present.
} 
dimensions (Amokrane, K., Andriot, C., Boccara, V., Carpentier, K., Convard, T., Delgoulet, C. et al., 2013): a) the coherency of the perceived environment: natural interactions, virtual environments which are graphically, physically and semantically realistic; b) emergence: freedom of action, confrontation with a wide variety of situations within a complex sociotechnical environment; c) control: dynamic adaptation, personalisation of learning situations and of assistance with interaction in accordance with the training objectives, intentions and learner profile. Within this overall objective, which essentially aimed to undo the scientific and technical "locks" ${ }^{10}$, numerous issues nevertheless came to light.

Our aim here is not to provide an exhaustive list of these issues, but to give an idea of their diversity. For example, our industrial partner already had a Virtual Reality (VR) department and had for several years been gambling on the fact that these technologies would help maintain and increase its competitiveness. By taking part in our project, it hoped to measure or even validate the added value of VR in training its assemblers. The training centre saw the project as an opportunity to occupy a new position in the training market and to reduce its training costs. For the prevention department, it was an opportunity to (re)examine the way workstations were currently designed and what was causing accidents (particularly among novices). As far as the methods department was concerned, the utility lay in the earlier familiarisation of trainees with the physical and organisational constraints of professional situations and with performance and quality requirements. At another level, the research team in charge of storytelling particularly wished to move ahead on issues of integration in their animated AVC model (Autonomous Virtual Characters), these being aspects which have not received much attention in the literature: restitution of the collective dimension, relating to coordinated situational action between the AVC and the trainee; or that of emotions when confronted with unexpected situations, etc.

In reference to Daniellou's works $(2004 ; 1992)$, in such a project the function of Project Ownership (POW) is comprised of two levels of actor - the ANR and the industrial partner. As the project funder, we can consider the ANR to be the first part of the project ownership, conveying a "desire in relation to the future" regarding the orientation of priority objects of national scientific research within the development of an economy of innovation and knowledge (MESR, 2009). The industrial partner and the training centre also conveyed in part a "desire in relation to the future" in terms of the preferred uses to be made of such a VTE in the professional training of production operators. The Project Management (PMA) - in charge of project feasibility - was made up of three research teams (which included the ergonomists) and of the 3D graphics company. Each team was responsible for a technical and scientific part of the future system, with one team being in charge of overall project management, particularly on behalf of the ANR.

As is quite often the case, it became obvious that there was no clear identification or presence within the project of the POW, which worked in favour of the PMA, "the project then being run by the technical element" (Daniellou, 2004; p.361). The place initially envisaged ${ }^{11}$ for the team of ergonomists was similar to the section of the PMA in charge of integrating human factors from a useroriented design perspective (Bastien \& Scapin, 2004): "a needs analysis phase involving future users, a design, test and completion phase, and an implementation and follow-up phase" (pp. 451-452). In reality, the approach went beyond the position initially envisaged, becoming located at the interface between the POW and the PMA, respectively represented by the industrial partner, its subsidiary and the research team in charge of the project. The ergonomists took part in this project with a view to transforming the work done and developing professional skills, with the dual objective of performance and health. The first stage of the demand analysis thus aimed to construct this position; in particular, this required the involvement of various company actors in addition to those already identified (the training centre director and the coordinator from the virtual reality department): trainers, teachers,

10 "Verrous" in French. Term systematically used by the ANR to qualify scientific challenges and issues.

${ }^{11}$ We wish to make it clear that we did not participate in the creation of the project, we joined it during the course of the first year. This paragraph therefore reflects our understanding of the initial organisation of the project, developed after reading the document responding to the call for projects and after the first discussions we had with the coordinators of the different partner teams when we joined the project. 
trainees, prevention department (occupational risk management staff, occupational doctor), internal ergonomist, journeymen, team managers $(\mathrm{N}+1)$, line managers $(\mathrm{N}+2)$ and the CHSCT.

The processes of understanding the project and analysing demand took place over a period of fifteen months: from the first contacts with our industrial partner and its subsidiary (initially limited to the possibilities of gaining access to the field of investigation) to the presentation of the study and its validation before the site's CHSCT. This phase allowed us to resize the scientific project through a reexamination of its "intentions" (Barcellini, Van Belleghem, \& Daniellou, 2013), not just by putting into perspective the knowledge developed in relation to the actual work and technological possibilities, but also in terms of the relevance, from a work standpoint, of the scientific options validated up to that point. It led to a shift from the initial objective of using Virtual Reality to teach "professional gestures" within a course built around a future VTE which would take full charge of the trainee, to a project, within a broader training context, to design a VTE which would help to develop the cognitive organisation of the action when performing assembly tasks (Boccara \& Delgoulet, 2013).

\section{2.- The work carried out by aeronautic assemblers}

\subsection{1.- Work organisation}

The work organisation is of a "lean manufacturing" type. Production takes the form of small or very small series of products. Because each aircraft is built for a specific airline company, there are numerous variations in assembly, depending on the options chosen by the customer. Before delivery, the aircraft parts move from one station to the next, on a flexible assembly line in the workshops. The work pace depends on the type of plane and more specifically on the efficiency of the production process. The "slowest" work pace is to be found at the station where the most recent aircraft are assembled; they are built at a rate of two per month (the first station studied). The "fastest" pace is found on the older production lines, with a rate of two days per plane. There are also intermediate categories, with three aircraft being produced per week (second station studied).

The teams are organised into two shifts $(2 * 8)$ with an overlap period of six minutes between the morning team (05:00-13:36) and the afternoon team (13:30-22:00) and a weekly rotation of the teams between the two shifts. Supervisors ensure that rules, procedures and directives are followed, with the threefold objective of guaranteeing quality, costs and deadlines.

The division of labour is decided when a team takes over a station, at 05:00 or 13:30. For reasons of responsibility or traceability of the work done, it is preferred that a journeyman carry out an operation from start to finish: if a person makes a mistake then he/she must correct it. However, given the time it takes to perform certain operations (sometimes several hours), journeymen are often obliged to work together on the same operation or to share sub-operations when this is materially or temporally possible.

\subsection{2.- Journeymen' tasks at the manufacturing stations}

The work done by journeymen is generally governed by directives (concerning use of tools, safety, quality) and by the rules governing the profession and procedures; these are provided in the construction plans for each aircraft element and in the work lists (parts, fittings, work schedules, regulatory documents to be consulted and allocated times). On a day-to-day basis the journeymen do not work with the plans in front of them. Their experience means that they have memorised the work to be done and the order in which it must be completed. The plans are nevertheless a useful resource when there is a doubt or where novices are concerned. For example, according to the journeymen who work there, it takes two years for an experienced journeyman to master the "hull" station we observed.

The tasks required at each of the two stations we studied are described as being part of the "finishing" phase. They consist in installing different fixed supports and fittings on the aircraft, which will serve, for example, to guide the passage of the electric cables or pipes that will power the plane and make it run. Five operations are thus programmed at the "hull" station, divided into 49 sub-operations for the upper section of this element (the interior of the fuselage). Their completion time is estimated at 128 man hours, with the element in question spending between two and three days at the work station. A 
total of 314 parts are fitted onto each hull by a team of four journeymen.

The journeymen must assemble the aeronautical parts using a set of fittings essentially made up of three main types of rivet and screw. Analysis of the required and effective tasks allowed us to identify eighteen elementary tasks which were systematically part of the operations performed by the journeymen and which thus formed the basis of the profession: boring, gluing, counter-boring, etching, burring, stapling, milling, drilling, bevelling, etc. In other words, they constitute the minimum basis of "what one needs to know and be able to do" in order to assemble aircraft parts. Depending on the fittings to be attached and the conditions for assembly, they are, can be or must be done in different orders. Each of these tasks is subject to standards of tolerance in the order of one tenth of a millimetre, or even one hundredth in certain cases. The journeyman's job thus requires extreme precision.

Moreover, these tasks are performed using a very wide range of tools and materials (dozens or even hundreds) specific to the profession. For example, we identified at least 45 tools which are used to carry out just the "basic" tasks: drill, rivet gun, pneumatic screwdriver, LGP riveter, drill (angled or otherwise), reamer, staple puller pliers, etc.

\subsection{3.- A wide variety of work situations}

Given the requirements of manufacturing in small series for several different models of aircraft, the journeymen's work is carried out in a wide variety of situations, and the way these situations are configured varies over time. Our observations and the exploratory interviews with the journeymen and their immediate superiors allowed us to identify the main aspects of this situational diversity and variability. Seven of these are listed below:

- levels of physical ambiance (sound, light, heat) which fluctuate depending on the task being performed by the journeymen or their colleagues (riveting is particularly noisy for example), on the work phase or on the time of year (fluctuations in ambient temperature and light sources between winter and summer);

— parts to be assembled which differ in size, thickness and weight; according to our observations, they are generally handled by a single journeyman, except where they have been prepared on a workbench as a sub-set which can be several metres in length;

— tools which differ in terms of weight (light/heavy), operation (manual/semi-automatic/automatic, etc.), condition (wear and tear, cleanliness), requiring different strategies and modus operandi: for example, when using a worn drill bit one has to exercise greater force on the drill and/or a faster rotation than when the bit is new;

— sections of the aircraft which are between $9 \mathrm{~m}^{2}$ and $15 \mathrm{~m}^{2}$, on which up to four journeymen might be working at the same time: this means that each one knows what he has to do and has organised his/her work space in such a way as to not disturb the others, reducing the amount of toing-andfroing between the workbench and the areas where tools and parts are stored. It also means they must be aware of how the work of the other journeymen is progressing and how their own work zone is temporarily organised;

- the work space configuration and assembly zone accessibility, which oblige the journeymen to very frequently change posture, thus causing a series of "atypical" postures which can be detrimental to health: riveting whilst sitting on a part, head forward; drilling or riveting whilst standing and bent forward, head down; drilling whilst balancing on a footstool with arms raised above the shoulders; drilling in a kneeling position, bent forwards, arms pushed in between gaps in the floor structure; drilling and riveting whilst lying down on metal transoms, etc.

— situations where two persons work together to perform riveting, requiring them to share a small work space which in most cases causes them to be in physical contact with one another: crouched in front of the rivet, shoulders touching, or lying down face to face, arms extended towards the riveting zone and also either side of a wall section. This proximity while working sometimes puts the journeymen in a paradoxical situation: a priori they can see what they are doing, but their physical proximity whilst performing the task can hide their own work and that of their colleague; 
- directives, procedures and rules (operations, quality, safety) which depending on the work situation are not always easy to put into practice; the wearing of certain items of $\mathrm{PPE}^{12}$ is a perfect example of this: it is impossible to wear a hard hat when one is working with the head bent forward or downward, or when working in physical contact with a partner - situations which regularly occurred at the two stations we observed.

\subsection{4.- Quality requirements and repairing defects}

As already explained, assembly work is very precise work, involving numerous dimensions of physical and cognitive action. Given the demands of production, defects are not uncommon. Some mistakes require the quality control department to issue derogations and organise ad hoc repair procedures which do not affect quality or final assembly. The company has defined ten categories of defect: drilling outside tolerance range, fuselage dents, scratches or deformations, accidental drilling of a part, etc. There are three levels of derogation: the bigger the repair, the more it costs, due to the involvement of the engineering department and the additional time required for the repair.

At the hull finishing station, 12,930 defects were identified over a period of four months; $75 \%$ of these were the object of a derogation. The most widespread defects were holes drilled outside ranges of tolerance $(43.3 \%)$. We also saw that "dents, scratches and deformations" represented a significant proportion $(31.7 \%)$; they were not directly linked to the performance of elementary professional tasks, but to the way tools were handled and to the movements of journeymen over the aircraft sections. In third place were "accidental holes" (19.3\%), i.e. holes accidentally drilled into parts located behind the part intended for drilling. The line managers believed these defects to be due to the work done by new recruits who had not checked the configuration of their drilling depth before beginning the task. They described them as having a major financial impact due to the time it takes to remove the accidentally drilled part, to scrap it, to order and assemble a replacement part, or to repair the damaged parts.

\subsection{5.- New recruits and work accidents}

In partnership with the prevention department, we worked on the database for work accidents which had occurred at the site over the six years leading up to our study (2006-2011). The database contained a total of 339 events i.e. approximately fifty recorded events per year.

In order to work on the transition phase between training and productive work, our accident analysis focused solely on the population of recently recruited journeymen (between 0 and 2 years of seniority, having previously taken a course at the training centre). It allowed us to identify a certain number of accidentology trends among novices who were for the most part under the age of 30 . Out of all accidents, 30\% (102/339) concerned novices. They were divided as follows: 52\% occurred when handling tools (drill, staple puller pliers) or professional equipment (53/102), 24\% related to falls (24/102), 14\% involved bumping into aircraft parts or frames and $10 \%$ concerned sudden pains (essentially back pains).

Injuries when handling tools or equipment (the most frequent) might occur when a journeyman is performing a task on his/her own: usually when preparing equipment or tools, carrying out maintenance on tools or when handling the staples which allow them to temporarily assemble a number of parts before definitively fixing them with screws or rivets. They can also occur when working in pairs (a journeyman injures his/her partner, a novice), usually when riveting. The parts of the body which are injured are: fingers (drilled, crushed, pinched, scraped), the face (flying staples, bumps against aircraft sections, metal shards flying into the eyes), the ankles (sprains caused by falls), the back (pains when carrying loads, when changing position, when doing heavy work).

\footnotetext{
${ }^{12}$ Personal Protective Equipment.
} 


\section{3.- Training work: trainer-trainee activity}

\subsection{1.- Training organisation}

As a reminder, the professional training of temporary workers takes place at the training site. Each session is comprised of 12 trainees wishing to obtain the CQPM certificate. The course is coordinated and run by one of the two trainers mentioned above. Each group is led by a trainer.

Two weeks of classroom lectures are devoted to technical and regulatory content divided into 15 themed modules. Our documentary analysis and interviews with the trainers demonstrated the scope of knowledge that the trainees have to acquire during these lessons. They cover parts, tools, fittings and the procedures to be used, specific to aeronautics. The content is presented in consecutive but separate modules (this aspect is accentuated by a succession of different contributors); the trainees have to work on the one hand on the links between the names of the objects, the tools, the tasks to be performed and the procedures and, on the other hand, on the representation of the dynamics of assembly work. Whilst the trainers try to take account of these links and expand on them, their training activity is hindered by a set of organisational factors: the separation of the two training areas (the workshop line and the classroom), with the difficulty of going back and forth between the two areas in order to illustrate what is being taught in the lectures, or, when the trainees are doing practical work $(\mathrm{PW})$, of returning to the classroom to re-examine underlying physical concepts and phenomena; the way the classroom is organised in rows of tables; the supports used for static lessons (slides, paper documents); and the short duration of the course compared to the volume of content to be taught.

Six weeks are then devoted to PW, comprising three exercises which take place on the training line under trainer supervision. These exercises are carried out on scaled-down aircraft smaller than those found on the actual production line. The workshop line is made up of a large workbench with twelve work stations, which is used for exercise 1, and three types of vertical frame (ten frames in total) used for the other two training exercises. The trainees mainly work in standing or kneeling positions, or on footstools, facing the work area. Two groups of trainees can work in parallel on the workshop line.

Both the two trainers and the trainees consider the shift from lectures to PW to be a critical period within the training process. The trainees we interviewed said they felt "lost" during their first two weeks on the workshop line. This was the period required to complete the first practical exercise, which involved most of the tools, fittings and basic tasks. The following quotes, taken from four interviews with trainees, offer a glimpse of the obstacles they face:

Trainee 1: "I was just a bit lost when it came to the tools, the names, and the different cutters, the solid cutters and all that, so it was the names".

Trainee 2: "At first I tended to confuse some things with other things, and I had to look at the text book to check ... depending on the process, or depending on the products we use, to degrease or to glue, or to ... and we do remember, but sometimes we get a bit mixed up, depending on the colour of the products or other things ...".

Trainee 3: "During the fortnight [of lectures] we didn't know what he [the trainer] was talking about [...]. But you can't match a word with an object that you're not familiar with, while you ... It's not easy. [...] He [the trainer] talked about 'cutter' or 'bucking bar'... a bit of everything, you know, the products we use. They are new words for us, we don't know those tools, so when we were in the workshop afterwards, he'd tell us to go and get this tool or that, he'd told us about them but we didn't know what to get".

Trainee 4: "When he [the trainer] talked to us in class, how can I put it ... you don't really see, you see it on the picture [photo or drawing of the tools and equipment discussed in class], but you don't really know what it is, what it does. So when you get to the workshop, at first it's not that easy, but you get used to it quite quickly. But then again, you're doing it every day ...”.

The links the trainees must make during the lectures thus become an object of learning during this initial period of practical work. More specifically, at the end of this exercise, the trainees said that they had mastered the links between the professional lexicon, the tools, the objectives to be achieved and 
the temporal order of operations to be performed. During this period, they had constructed "what needs to be done" in interaction with "how to do it" (what resources to use) - a construction which continued throughout the two other training exercises. The feeling of "being lost" during the first two weeks of the workshop thus stemmed from the difficulties they had in understanding "what needs to be done" which prevented them from constructing a "how to do it". In other words, they had difficulties in identifying the explicit and implicit aspects of the task to be performed, despite the fact that technical instructions containing detailed diagrams and explanations were provided to guide them in completing the task.

\subsection{2.- The educational dimension of working on the workshop line}

Of all the observations made during the workshop line sessions, lets us keep in mind that the educational activity of trainers involves organising the training sessions and the "guidance" of the trainees as they do the exercises. Because lecture and PW content has been determined and validated by the professional branch which issues the CQP certificate (Metallurgy), trainers have little leeway in this area. On the other hand, they must keep a constant eye on the availability of the premises, on the coordination of the two groups receiving parallel training, on the organisation of training sessions, on the availability of contributors from the production departments (who might change or cancel their classes at any moment due to production constraints taking precedent over training) - and all of this whilst making sure that their progression has meaning for the trainees. The trainers have a dual role when it comes to guidance: in turns, or together, they are "assistants" and "assessors" of the finished work. As assistants, they orientate ("what needs to be done") and support the trainees in their learning, using technical, regulatory and professional know-how (how to do it). As assessors, they check what the trainees have learned. During the training process, these two roles give the trainers opportunities to transpose the critical aspects of production situations by temporarily taking on the role of a line manager, of a quality controller or of another journeyman, in a fashion similar to language simulation (Nicolas, 2000a; 2000b; Béguin \& Weil-Fassina, 1997) for educational purposes. They also play on organisational factors: lack of tools, their wear and tear, poor tool storage, the collective aspects of the work (inter-dependency of tasks between journeymen, space and tool sharing, etc.) or the overcrowding of work stations and its consequences on the work. These simulations can be either preplanned or spontaneous, depending on the training situation and on the mistakes or interventions of the trainees. They thus constitute opportunities for learning about aspects of the job that the workshop line, as a training device, does not intrinsically offer, but that the trainers - as former journeymen in the production workshop - can introduce through their own personal experience.

From another standpoint (Rogalski, 2003), interventions by the trainers act and/or react to the development dynamic of the trainees' skills. Their interventions are thus partly based on the diagnosis they make of the state and possible development of the trainees' skills, and on how they believe their interventions will affect this development. As has been observed in other works (Antolin-Glenn, 2005; Boccara, 2011; Vidal-Gomel, 2001), trainer interventions may be characterised in terms of mode (both groups, a single group, a single trainee, etc.), of form (explanation, correction, guidance, etc.) and content (objectives, subject matter, rules, procedures, etc.; Boccara, 2011) and their relation to the profession (regulatory, technical, safety, ethical, etc.). During the interviews the trainers stressed the importance of talking to the group as a whole, in order to avoid having to repeat and to ensure that explanations are homogeneous. They also feel that demonstration helps trainees to understand, particularly when it comes to illustrating and explaining indicators which are difficult to explain in words, such as noise, time or tactile sensations. Demonstrations are therefore used "to make trainees see what cannot be seen" when one is not part of the profession. In addition, the trainers constantly "walk around" the workshop, intervening in an opportunistic manner when they see that trainees are having difficulties or making mistakes in situ. This strategy also makes it easier for trainees to ask for guidance whilst doing the exercises. In this way the trainers are able to monitor their trainees both collectively and individually.

Using the co-construction device (cf. phase 3 of the approach) and previous works carried out on this professional sector (Aubert-Blanc, 2009), we reconstituted two conceptual structures (Pastré, 1999; 2011): the first underpins tasks of drilling, counter-boring and reaming; the second underpins the task 
of riveting, either alone or in a pair. We thus highlighted three pragmatic concepts ${ }^{13}$ : "squareness" and "advance ${ }^{14}$ " for the first conceptual structure; 2) "squareness" and "bucking ${ }^{15}$ " for the second. These conceptual structures were the subject of discussion between the two trainers, who improved them prior to validation. As from the very first exercise, with help from the trainers, the trainees are required to go through the motions so as to gradually mobilise and construct these concepts. Right from the start of the training course in the workshop, the trainers discuss said concepts (e.g. squareness, advance, etc.), parameters (e.g. speeds of rotation, accessibility of holes, etc.) and indicators (e.g. thickness, what the parts are made of, greasing, wear and tear, dimeter of the drill bits used). These elements are not introduced one after the other without there being and explicit link between them. On the contrary, the trainers explain the relationships between the different items necessary to the identification of the state of the situation and the operations required. They clarify the "links" that the trainees must establish if they are to understand the situations they are facing and what they need to do. However, whilst these concepts are taught by the trainers, they do not appear to be the object of any formalised and structured transposition to help the trainees develop them during the course. It is therefore likely that the conceptual structures highlighted will become future tools for training course design: the assessment of exercises and existing progression, but also the creation of new exercises for future training situations.

\section{4.- Discussion and Conclusion}

This study, which aims to inform existing work situations (in production and training) is thus part of a perspective for ergonomic intervention where artefact design does not just mean proposing criteria for "ergonomic" design or evaluation. It is also about offering the actors involved in design opportunities for development (Rabardel, 1995) - in this case those we met in a training context (trainees and trainers), in production (ergonomist, preventers and journeymen) and in design (computer engineers, manufacturers and designers, project partners). As Béguin and Cerf (2004) point out, design can have several purposes, including that of designing for geneses. This design horizon goes beyond the end of the formal design process (the project). It is an invitation to anticipate possible appropriations and uses which may, in certain cases, lead to transformations or reconfigurations of the artefact. During the project it therefore introduces a reflection on the boundaries of the system, the room for manoeuvre that they offer or which might encourage development.

Above and beyond our contribution (through an analysis of what already exists) to the design of a VTE within the framework of a research project, the work analysis allows us to take account of the stakes of the various scientific and industrial partners involved in this project, in addition to those led by the actors on the ground. During the course of this approach, because the focus of the analysis, the actors involved and the results produced all evolve, a dialogical design process is created which both encourages and causes compromises to be made. As part of this developmental objective (Béguin, 2007) we find, for example, trade-offs between the desires of future users (management, trainers or trainees) and existing technological possibilities; or between scenarii which are technically possible, offering new scientific challenges to researchers and designers, and those which are more desirable from the standpoint of skill development, of protecting the health of future journeymen, or of the room for manoeuvre of trainers and hence of system performance. The design of training artefacts within the framework of a works analysis is thus also an opportunity to re-examine productive work and the

13 The terms used in the French text come from the professional terminology used by French journeymen. The terms employed in the translation are not necessarily those used by professional journeymen in the British aeronautics industry.

14 The pragmatic concept of "advance" refers to the drill bit's progession through the material; it essentially depends on the pressure a person applies to the drill, the rotation speed of the bit, its diameter, its cutting edge and the quality of the material; but it also depends on the type of part being drilled or counter-bored and on its thickness.

15 The pragmatic concept of "bucking" refers to the gradual compression of the rivets, which mainly depends on the characteristics of the rivet (shape, diameter, length, material, etc.), on the impact on the rivet head (pistol and head type, force, frequency and duration) and on the "bucking bar" (size, shape, material) used as a counterpoint to facilitate rivet bucking (thickness, material force exerted). 
actors who organise it (concerning the organisational choices made or the tools used to monitor prevention, to give but two examples). In this respect we follow the tradition of ergonomists who, through training, aim to transform work (Falzon \& Teiger, 2011; Lacomblez, Bellemare, Chatigny, Delgoulet, Re, Truel, \& Vasconcelos, 2007). When designing a VTE, the scope of researchintervention was originally confined to existing work situations. One of the challenges of our "works" analysis approach was to extend this scope by more broadly involving actors from the production site (prevention, occupational medicine, ergonomics and production) and from the training centre (trainers and trainees). We were not tasked with transforming the work situations (production or training); this extension thus aimed to integrate the aforementioned actors so that they could make an internal contribution towards improving work situations, using the analyses produced during the project. It was based on a demand analysis integrated into a project analysis. This was justified both by the format of the responses to this type of project (broken down into tasks and sub-tasks, focus on scientific knowledge which already exists or which will be developed, and its areas of application) and by the time constraints imposed by the funding party (response to be supplied several months after the call) which made it difficult, straight after the response, to implement a properly coordinated approach between the industrial partner and the research teams. Moreover, our absence during the preparation and start of the project undoubtedly contributed towards our need for clarifications when we joined. Retrospectively, this phase contained strategic challenges regarding the role of the different actors, the structures for discussion/dialogue and decision-making, the scope, the orientation and the project story, which would encourage this type of analysis to be generalised as an entirely separate researchintervention phase. It was indeed this phase which made it possible to include the trainers in the device for analysing training situations, which helped bring to light the changes needed in their working situation (adapting the training premises, improving the pedagogical tools) and triggered reflection on their own training practices which was favourable to their development and to the preservation of their room for manoeuvre.

More specifically, the work analysis approach is intended to produce and sustain a frame of reference of situations (Boccara, et al., 2014; Mayen, et al., 2010) synthesizing design clues which fulfil the role of intermediary objects within the design process (Jeantet, 1998; Vinck, 2009). This frame of reference of training situations integrates: 1) organisational and situational factors in production and training, 2) potential sources of accidents and defects in production, 3) tasks, processes, rules and tools, and 4) elements relating to pragmatic conceptualisation and to the organisers of the journeymen's activity. This frame of reference was designed with the dual objective of an operational tool for: 1) training course design managers (trainers, teachers and the training centre director); 2) the VTE designers, with a view to proposing potential development situations in and with the future VTE (Mayen, 1999).

From the standpoint of current training course design, the films made with the two trainers complemented the lectures by offering the possibility of setting in motion and taking account of the dynamic of assembly work which has until now only been examined in a purely static manner - a form which satisfied neither trainers nor trainees (see above). The frame of reference of situations attracted the interest of the various actors. It nevertheless supposes a work of appropriation which has not yet been carried out by actors involved in training course design. The conditions for this appropriation and for the possible support processes undoubtedly constitute a field of research to be investigated in order to strengthen the role of ergonomists in training course design.

From the point of view of VTE design, the frame of reference of situations was a resource and a tool with which to define and construct the material interface (commands, technical device, etc.) and the software interface with a set of training scenario, potentially mobilising virtual agents and satisfying the different modes of use depending on the type of real training situations envisaged (in the classroom vs. in the workshop, individual vs. group, with a trainer vs. without a trainer, etc.). The suggested frame of reference thus offers a set of elements which may be used and combined in various ways, in order to simulate training situations in line with the questions asked during the design process and as they evolve. It also helps to guide the functional analysis and the development of specifications with and for the design team, taking into account the utility, the usability and the learning aspect of the 
future system (Delgoulet \& Boccara, 2013).

In conclusion, works analysis opens up perspectives for research and intervention in the field of professional training and, more particularly, for the design of training devices, tools and/or content. The example discussed here underlines the potential of re-examination with the aim of transforming work situations in production and training, on the one hand using training demands as an entry point, and on the other hand with a view to redirecting and being more precise about the intentions of the design project. Finally, it allows us to think about the multiple objects and purposes of design processes in order to go beyond approaches which focus on the development and respect of "ergonomic" criteria.

\section{ACKNOWLEDGEMENTS}

This work was funded by the Agence Nationale de la Recherche (ANR-10-CORD-0014). We would also like to give our heartfelt thanks to the trainers and all of the participants at the production and training sites, without whom this work would not have been possible.

\section{BIBLIOGRAPHY}

Amigues, R. (2003). Pour une approche ergonomique de l'activité enseignante. Skholê, hors-série 1, 5-16.

Amokrane, K., Andriot, C., Boccara, V., Carpentier, K., Convard, T., Delgoulet, C., Guerriero, E., Lourdeaux, D., Vinchon, G., \& Wagrez, K. (2013). Des STIC et des hommes. Nikita: Natural Interactions, Knowledge, Immersive system for Training in Aeronautic. Les rencontres du numérique de l'ANR, les 17 et 18 avril, Paris.

Anastassova, M., \& Burkardt, J.-M. (2009). Automotive technicians' training as communitu-of-practice: implementation for the design of an augmented reality teaching aid. Applied ergonomics, 40, 713-721.

Anastassova, M., Burkhardt, J.-M., Mégard, C., \& Ehanno, P. (2005). Results from a usercentred critical incidents study for guiding future implementation of augmented reality in automotive maintenance. International Journal of Industrial Ergonomics, 35(1), 81-91.

Anastassova, M., Burkhardt, J.-M., Mégard, C., \& Ehanno, P. (2007). L'ergonomie de la réalité augmentée pour l'apprentissage. Le Travail Humain, 70(2), 97-125

Antolin-Glenn, P. (2005). Le développement des compétences à la coopération dans la formation à la prise de décision distribuée hiérarchisée. Le cas de la formation continue à la gestion opérationnelle des officiers sapeurs pompiers. Thèse de Doctorat, Université Paris 8, Saint-Denis.

Arborio, A.-M., \& Fournier, P. (1999). L'enquête et ses méthodes: l'observation directe. Paris: Nathan Université.

Aubert-Blanc, S. (2009). Apport de l'ergonomie à la définition du contenu des savoir-faire de métier et à l'organisation de leur transmission. «C'est pas compliqué de percer un trou! ». Séminaire «Transmission des savoirs et mutualisation des pratiques en situation de travail » (pp. 33-41). Rapport de recherche du CEE.

Barcellini, F., Van Belleghem, L. et Daniellou, F. (2014). Design projects as opportunities for the development of activities. In P. Falzon (Ed.) Constructive ergonomics. USA : Taylor and Francis

Bastien C., \& Scapin, D. (2004). La conception de logiciels interactifs centrés sur l'utilisateur : étapes et méthodes. In, P. Falzon (Ed.), Ergonomie (pp. 451-462), Paris: PUF.

Beaujouan, J., Aubert, S. \& Coutarel, F. (2013). Formateur-animateur : un rôle sous-estimé et à outiller dans la conception de dispositifs de formation. Cas de la formation de dispositifs de formation. Cas de la formation aux opérations de contre-perçage sur avion. Journées Scientifiques de Nantes, 5-7 juin 2013. https://hal.archives-ouvertes.fr/hal-00973460.

Béguin, P. (2007). Prendre en compte l'activité de travail pour concevoir. Activités, 4(2), 107-114.

Béguin, P., \& Cerf, M. (2004). Formes et enjeux de l'analyse de l'activité pour la conception des systèmes de travail. Activités, 1(1), 54-71.

Béguin, P., \& Weil-Fassina, A. (1997). La simulation en ergonomie : connaître, agir et interagir. Toulouse: Octarès.

Berglund, M., \& Karltun, A. (2012). Towards understanding and managing the learning process in mail sorting. Work, 41(2), 115-126. 
Berthelette, D. (1995). L'évaluation de programmes de formation en ergonomie. Éducation permanente, 124(3), 97-109.

Blanchet, A., \& Gotman, A. (1992). L'enquête et ses méthodes : l'entretien. Paris: Nathan.

Boccara, V. (2011). Développement des compétences en situation de tutelle au cours de la formation à la conduite automobile. Apports croisés de la psychologie ergonomique et de la psychologie sociale. Thèse de Doctorat, Université Paris 8, St-Denis.

Boccara, V., \& Delgoulet, C. (2013). Articuler les démarches d'analyse du travail en ergonomie et en didactique professionnelle pour la conception d'un EVAH. Journées Scientifiques de Nantes, 5-7 juin 2013.

Boccara, V., Vidal-Gomel, C., Rogalski, J., \& Delhomme, P. (2014). Concevoir des référentiels comme des outils pour les formateurs? Réflexions à partir de la formation initiale à la conduite automobile. In B. Prot (Ed.), Référentiel, Compétences, Développement. (pp. 119-132). Toulouse: Octarès.

Brough, J.E., Schwartz, M., Gupta, S.K., Anand, D.K., Kavetsky, R., \& Pettersen, R. (2007). Towards the development of a virtual environment-based training system for mechanical assembly operations. Virtual Reality, 11, 189-206.

Cau-Bareille, D. (2011). Factors influencing early retirement in a femal-dominated profession: Kindergarten teacher in France. Work, 40(Suppl.), 15-30.

Cau-Bareille, D., Gaudart, C., \& Delgoulet, C. (2012). Training, age and technological change : difficulties associated with age, the design of tools, and the organization of work. Work,41(2), 127-141.

Chatigny, C., Levesque, S., \& Riel, J. (2012). Training yourself while training students: The constant challenge of vocational training teachers. Work, 41(2), 143-153.

Chatigny, C., \& Vezina, N. (1995). Analyse du travail et apprentissage d'une tâche complexe ; étude de l'affilage du couteau dans un abattoir. Le Travail Humain, 58(3), 145-162.

Chatigny, C., \& Vezina, N. (2008). L'analyse ergonomique de l'activité de travail : un outil pour développer les dispositifs de formation et d'enseignement. In Y. Lenoir (Ed.), Didactique professionnelle et didactiques disciplinaires en débat. (pp. 127-159). Toulouse: Octarès.

Clot, Y. (2000). La fonction psychologique du collectif. In H. Benchekroum \& A. Weil-Fassina (Eds.), Approches du collectif, Toulouse: Octarès.

Cloutier, E., Fournier, P.-S., Ledoux, É., Gagnon, I., Beauvais, A., \& Vincent-Genod, C. (2012). La transmission des savoirs de métier et de prudence par les travailleurs expérimentés : comment soutenir cette approche dynamique de formation dans les milieux de travail. Rapport, Montréal: Commission des partenaires du marché du travail.

Clot, Y., Faïta, D., Fernandez, G., \& Scheller, L. (2000). Entretiens en autoconfrontation croisée : une méthode en clinique de l'activité. PISTES, 2(2).

Costello, P. (1997). Health and Safety Issues associated with Virtual Reality - A Review of Current Literature, AGOCG Technical Report Series.

Daniellou, F. (1996). L'ergonomie en quête de ses principes. Toulouse: Octarès Éditions.

Daniellou, F. (2004). L'ergonomie dans la conduite de projets de conception de systèmes de travail. In P. Falzon (Ed.), Ergonomie. (pp. 359-373). Paris: PUF.

Delgoulet, C. (2001). La construction des liens entre situations de travail et situations d'apprentissage dans la formation professionnelle. PISTES, 3(2). http://www.pistes.uqam.ca

Delgoulet, C. (2012). Being a trainer in the French vocational training system: a case study on job status and working conditions related to perceived health. Work, 41(suppl.), 5203-5209.

Delgoulet, C., \& Boccara, V. (2013). Analyse du travail des monteurs - ajusteurs de l'aéronautique en production et en formation pour la conception d'un environnement virtuel de formation. Rapport intermédiaire $\left(n^{\circ} 2\right)$ Nikita, LATI - ANR, janvier.

Delgoulet, C., Largier, A., \& Tirilly, G. (2013). La mesure des tutorats en entreprise: enjeux, complexité et limites. Formation - Emploi, 124, 45-62.

Delgoulet, C., \& Marquié, J.-C. (2002). Age differences in learning maintenance skills: a field study. Experimental Aging Research, 28, 25-37.

Delvolvé, N., \& Davila W. (1994). Effets de la semaine de classe de quatre jours sur l'élève : Les rythmes scolaires en Europe, Enfance, 4, 400-407.

Desnoyers, L., Berthelette, D., Gourde, D., \& Authier, M. (1997). Évaluation d'un programme de formation en 
santé et en sécurité du travail. Actes du 32ème congrès de la SELF : Recherche, pratique et formation en ergonomie (pp. 335-346). Lyon: Editions GERRA.

Faïta, D. (2003). Apport des sciences du travail à l'analyse des activités enseignantes. Skhôlé, hors série 1,1723.

Falzon, P., \& Mollo, V. (2004). Auto- and allo-confrontation as tools for reflective activities. Applied Ergonomics, 35, 531-540.

Falzon, P., \& Teiger, C. (2011). Ergonomie et formation. In, P. Carré \& P. Caspar (Eds.), Le traité des sciences et techniques de la formation (pp. 145-162), Paris: Dunod.

Gaudart, C. (2000). Conditions for maintaining ageing operators at work - a case study conducted at an automobile manufacturing plant. Applied Ergonomics, 31(5), 453-462

Gaudart, C., Delgoulet, C., \& Chassaing, K. (2008). La fidélisation de nouveaux dans une entreprise du BTP : Approche ergonomique des enjeux et des déterminants. Activités, 5(2), 2-24. http://www.activites.org/ v5n2/v5n2.pdf

Gaudart, C., Petit, J., Dugué, B., Daniellou, F., Davezies, P., \& Théry, L. (2012). Impacting working conditions through trade union training. WORK, 41(2), 165-175.

Guérin, F., Laville, A., Daniellou, F., Duraffourg, J., \& Kerguelen, A. (1991). Comprendre le travail pour le transformer. Lyon: Éditions ANACT.

Guilbert, L., \& Lancry, A. (2007). L'analyse des activités des cadres : l'intérêt de la triangulation des méthodes. Le Travail Humain, 70(4), 313-342.

Haradji, Y., Kostulski, K., Morais, A., \& Ughetto, P. (2014). Éditorial. Activités, 11(2), 1-2. http://www.activites.org/v11n2/V11n2.pdf

Hu, B., Zhang, W., \& Salvendy, G. (2012). Impact of Multimodal Feedback on Simulated Ergonomic Measurements in a Virtual Environment: A Case Study with Manufacturing Workers. Human Factors and Ergonomics in Manufacturing and Service Industries, 22(2), 145-155.

Hubault, F., Noulin, M., Dupont, F., \& Mélier, B. (1994). Formation par et pour l'action: exemples d'apprentissage de la conduite de projet intégrant le point de vue du travail. Actes du congrès IEA'94 (pp. 7173). Toronto (Canada), 15-19 Août 1994.

Jacobs, K., \& Backer, N.A. (2002). The association between children's computer use and musculoskeletal discomfort. Work, 18(2), 221-226

Jeantet, A. (1998). Les objets intermédiaires dans les processus de conception de produits. Sociologie du travail, 98(3), 291-316.

Jick, T. D. (1979). Mixing qualitative and quantitative methods: triangulation in action. Administrative Science Quarterly, 24(4), 602-611.

Jobert, G. (1987). Une nouvelle professionnalité pour les formateurs d'adultes. Éducation Permanente, 87, 19-33

Jobert, G. (1993). Les formateurs et le travail : chronique d'une relation malheureuse. Éducation Permanente, $116,7-18$

Jobert, G. (2000). Dire, penser, faire. À propos de trois métaphores agissantes en formation des adultes. Éducation Permanente, 143, 7-28.

Lacomblez, M., Bellemare, M., Chatigny, C., Delgoulet, C., Re, A., Trudel, L., \& Vasconcelos, R. (2007). Ergonomics analysis of work activity and training: basic paradigm, evolutions and challenges. In R. Pikaar, E. Konongsveld, \& P. Settels (Eds.) Meeting Diversity in Ergonomics (129-142). Elsevier Ltd.

Lang, N. (2013). Évaluation d'une formation à l'analyse ergonomique du travail pour des enseignants de lycée professionnel. In C. Teiger \& M. Lacomblez (Eds.), (Se) former pour transformer le travail. Dynamique de constructions d'une analyse critique du travail (pp. 582-593), Laval Québec: PUL.

Leplat, J. (1955). Analyse du travail et formation. Bulletin du CERP, 4(9), 175-184

Leplat, J. (2002). De l'étude de cas à l'analyse de l'activité. PISTES, 4(2).

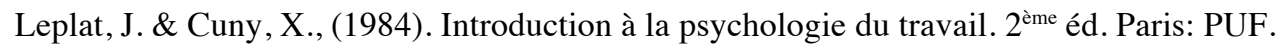

Leppänen, A. (2001). Improving the mastery of work and the development of the work process in paper production. Industrial Relations, 56(3), 576-609.

Mayen, P. (1999). Des situations potentielles de développement. Éducation Permanente, 139, 65-86.

Mayen, P., Métral, J.-F., \& Tourmen, C. (2010). Les référentiels en formation : enjeux, légitimité, contenu et usage. Recherche et formation, 64, 31-46. 
Méhaut, P. (1995). Le rôle de l'entreprise dans la production des qualifications : effets formateurs de l'organisation du travail. Luxembourg: Office des Publications des Communautés Européennes.

Messing, K., Escalona E., \& Seifert, A.M. (1996). La minute de 120 secondes, analyse du travail des enseignantes de l'école primaire. Rapport Centre D'enseignement du Québec - CINBIOSE.

Montmollin (de), M. (1974). L'analyse du travail : Préalable à la formation. Paris: Armand Colin.

Montmollin (de), M. (1980). Ergonomie et organisation du travail. In J. Leplat (Ed.), L'analyse du travail (Vol. 1). Toulouse: Octarès.

Montreuil, S., Brisson, C., Arial, M., \& Trudel, L. (1997). Évaluation des effets d'un programme de formation chez les utilisateurs de terminaux à écran de visualisation. Rapport de recherche de l'IRSST R-167, Montréal: IRSST.

Nicolas, L. (2000a). L'activité de simulation en analyse fonctionnelle : vers des outils anthropocentrés pour la conception de produits automobiles. Thèse de Doctorat en Ergonomie. Paris: CNAM.

Nicolas, L. (2000b). La simulation Langagière en analyse fonctionnelle : entre travail des concepteurs et travail des ergonomes. Actes du 35ème congrès de la SELF : Communication et Travail (pp. 178-187). Toulouse. http://www .ergonomie-self.org/documents/35eme-Toulouse-2000/conception.pdf

Olry, P., \& Vidal-Gomel, C. (2011). Conception de formation professionnelle continue : tensions croisées et apports de l'ergonomie, de la didactique professionnelle et des pratiques d'ingénierie. Activités, 8(2), 115149. http://www.activites.org/v8n2/v8n2.pd

Ombredane, A., \& Faverge, J.M. (1955). L'analyse du travail. Facteur d'économie humaine et de productivité. Paris: PUF.

Ouellet, S., \& Vézina, N. (2008) Savoirs professionnels et prévention des TMS : réflexions conceptuelles et méthodologiques menant à leur identification et à la genèse de leur construction. PISTES, 10(2), www.pistes.uqam.ca/v10n2/articles/v10n2a5.html

Ouellet, S., \& Vézina, N. (2009). Savoirs professionnels et prévention des TMS : portrait de leur transmission durant la formation et perspectives d'intervention. PISTES, 11(2). http://www.pistes.uqam.ca/v11n2/articles/v11n2a4.htm

Ouellet, S., Vézina, N., Chartrand, J., Perrier P.-P., \& Malo J.-L. (2003). L’implantation de la rotation de postes : un exemple de démarche préalable. PISTES, 5(2). www.pistes.uqam.ca/v5n2/articles/v5n2a14.htm

Ouellet, S., Vézina, N., \& Chatigny, C. (2013). Transformer les conditions d'apprentissage par la transformation des conditions de travail du formateur. Colloque international. Les questions vives en éducation et formation : regards croisés France-Canada. Nantes: CREN.

Pacaud, S. (1975). Le travailleur vieillissant : quelques réflexions sur ses difficultés, mais aussi ses facilités d'adaptation au travail. In A. Laville, C. Teiger, \& A. Wisner, (Eds.), Age et Contraintes de Travail. Aspects sociologiques, psychologiques, physiologiques (pp. 115-179), Paris: NEB Editions Scientifiques.

Pastré, P. (1999). La conceptualisation dans l'action : bilan et nouvelles perspectives. Éducation permanente, $139,13-35$.

Pastré, P. (2005). Dynamique et métamorphose des compétences professionnelles. Psychologie du travail et des organisations, 11, 73-87.

Pastré, P. (2011). La didactique professionnelle : approche anthropologique du développement chez les adultes. Paris: PUF.

Rabardel, P. (1995). Les hommes et les technologies. Paris: Armand Collin.

Rabardel, P., Teiger, C., Laville, A., Rey, P., \& Desnoyers, L. (1991). Ergonomic work analysis and training. In Y. Quéinnec, \& F. Daniellou (Eds.), XIth Congress of International Ergonomics Association, Designing for everyone (pp. 1738-1740). London: Taylor and Francis.

Rabardel, P., Carlin, N., Chesnais, M., Lang, N., \& Pascal, M. (1998). Ergonomie concepts et méthodes. Toulouse: Octarès Editions.

Rabardel, P., \& Six, B. (1995). Outiller les acteurs de la formation pour le développement des compétences au travail. Éducation permanente, 123(2), 33-46.

Ria, L., Sève, C., Durand, M., \& Bertone, S. (2004). Indétermination, contradiction, exploration: trois expériences typiques des enseignants débutants en éducation physique. Revue des sciences de l'éducation, 30(3), 535-554.

Riel, J., \& Messing, K. (2011). Counting the minutes: Administrative control of work schedule and time management of secondary school teachers in Québec, Work,40(1), 59-70. 
Rogalski, J. (2003). Y a-t-il un pilote dans la classe ? Une analyse de l'activité l'enseignant comme gestion d'un environnement dynamique ouvert. Recherche en didactique des mathématiques, 23, 343-388.

Rogalski, J. (2004). La didactique professionnelle: une alternative aux approches de « cognition située » et « cognitiviste » en psychologie des acquisitions. Activités, 1(2), 103-120. http://www.activites.org/v1n2/Rogalski.pdf.

Rogalski, J. (2012). Théorie de l'activité et didactique, pour l'analyse conjointe des activités de l'enseignant et de l'élève. Jornal Internacional de Estudos em Educaçao Metamatica, 5(1), 1-37.

Samurçay, R., \& Rabardel, P. (2004). Modèles pour l'analyse de l'activité et des compétences, propositions. In R. Samurçay \& P. Pastré (Eds/), Recherches en didactique professionnelle (pp. 163-180). Toulouse: Octarès.

Samurçay, R., \& Rogalski, J. (1998). Exploitation didactique des situations de simulation. Le Travail Humain, 61(4), 333-359.

Santos, M., \& Ferreira, A. (2012). Conditions, demands and constraints on trainers' activity: a case study in the Portuguese context. Work, 41(suppl.), 5210-5217

Santos, M., \& Lacomblez, M. (2007). Que fait la peur d'apprendre dans la zone prochaine de développement? Activités, 4(2), 16-29. http://www.activites.org/v4n2/santos.pdf

Teiger, C., \& Lacomblez, M. (Eds) (2013). (Se) former pour transformer le travail. Dynamique de constructions d'une analyse critique du travail. Laval Québec: PUL.

Teiger, C., \& Laville, A. (1991). L'apprentissage de l'analyse ergonomique du travail, outil d'une formation pour l'action. Travail et emploi, 47, 53-62.

Teiger, C., \& Montreuil, S. (1996). The foundations and contributions of ergonomics work analysis in training programs, Safety Science, 23(2/3), 81-95.

Thébault, J. (2013). La transmission professionnelle: processus d'élaboration d'interactions formatives en situation de travail. Une recherche auprès de personnels soignants dans un Centre Hospitalier Universitaire. Thèse de doctorat, CNAM, Paris.

Thébault, J., Delgoulet, C., Fournier, P. S., Gaudart, C., \& Jolivet, A. (2014). La transmission à l'épreuve des réalités du travail. Éducation permanente, 198, 85-99.

Thébault, J., Gaudart, C., Cloutier, E., \& Volkoff, S. (2012). Transmission of vocational skills between experienced and new hospital workers. Work, 41(1), 195-204.

Veyrac, H., \& Asloum, N. (2009). Les tâches appropriées des professeurs d' enseignement professionnel. Illustration du hiatus entre travail en entreprise et formation. Activités, 6(1), 69-86. http://www.activites.org/v6n1/v6n1.pdf

Viau-Guay, A. (2014). L'intégration des savoirs théoriques, pratiques et d'autorégulation chez les apprenants: analyse de l'activité d'enseignants en formation professionnelle et contribution à la formation à l'enseignement. Activités, 11(2), 88-111, http://www.activites.org/v11n2/v11n2.pdf

Vidal-Gomel, C. (2001). Le développement des compétences pour la gestion des risques professionnels. Le domaine de la maintenance des systèmes électriques. Thèse de Doctorat, Université: Paris 8, St-Denis.

Vidal-Gomel, C., Boccara, V., Rogalski, J., \& Delhomme, P. (2012). Sharing the driving-course of a same trainee between different trainers, what are the consequences? Work: A Journal of Prevention, Assessment, \& Rehabilitation, 41, 205-215.

Vinck, D. (2009). De l'objet intermédiaire à l'objet-frontière. Revue d'anthropologie des connaissances, 3(1), 5172.

Weill-Fassina, A., \& Pastré, P. (2004). Les compétences professionnelles et leur développement. In P. Falzon (Ed.), Ergonomie (pp. 213-232). Paris: PUF.

Wendelen, E. (1996). Training trade unionists in ergonomics: interaction between public policies, trade union practices and development of research. Safety Science, 23(2:3), 107-117.

\section{RESUME}

Cet article présente et discute une démarche d'analyse « des travails » dans le cadre d'un projet de conception d'un environnement virtuel de formation $(E V F)$ au métier d'assembleur-monteur en aéronautique. Cette démarche, à la croisée de l'ergonomie et de la didactique professionnelle, a été menée en trois phases : 1) une analyse de la demande et du projet, 2) une analyse des 
travails (formateurs, formés, opérateurs de production), 3) un dispositif de co-analyse des savoirs de métier et de leurs modalités de transmission, impliquant les formateurs. Au cours de cette démarche, la focale de l'analyse du travail, les acteurs impliqués ainsi que les résultats produits évoluent. À partir d'une réflexion sur notre pratique d'ergonome, il s'agit de discuter des apports d'une analyse « des travails » comme moyen d'identifier les multiples horizons des situations de formation à concevoir et d'intervention en conception.

\section{MOTS-CLES}

conception, formation, environnement virtuel, analyse des travails, aéronautique

\section{REFERENCEMENT}

Boccara, V., \& Delgoulet, C. Works analysis in training design. How ergonomics helps to orientate upstream design of virtual training environments. Activités, 12(2), 137-158. http://www .activites.org/v12n2/V12n2.pdf

Article submitted 29 juillet 2014, accepted 18 juin 2015 